\title{
Structural Performance of a Hybrid Girder Cable-Stayed Bridge during Rotation Construction
}

\author{
Liu $B^{1}$, Wang $Z^{2}$, Deng $L^{3 *}$ and Dong $S^{1}$ \\ ${ }^{1}$ The Second Engineering Co., LTD, China Railway No.9 Group, China \\ ${ }^{2}$ Changji Intercity Railway Co., LTD, China \\ ${ }^{3}$ College of Civil Engineering, Hunan University, China
}

\begin{abstract}
The structure of hybrid girder cable-stayed bridges with single pylon and single cable plane is very complex, which leads to their complicated structural behavior and adds difficulties to their construction. Few studies have been conducted to investigate the structural performance of such bridges under rotation construction. In the present study, the structural performance of a hybrid girder cable-stayed bridge with single pylon and single cable plane during rotation construction is simulated with the Midas/Civil program. The deflection and the stress of the bridge girder and the deformation of the pylon at different construction stages during the rotation construction are investigated and are checked against the bridge design code. The camber for the bridge girder is also studied. The findings from this study provide useful reference for the design of such bridges for rotation construction and the control of the bridges during rotation construction.
\end{abstract}

Keywords: Cable-stayed bridge; Rotation construction; Structural performance; Finite element analysis

\section{Introduction}

Bridge rotation construction $[1,2]$ refers to a bridge construction method in which the main structure of the bridge is constructed outside its designated position and is then rotated to the final position with traction equipment. The closure of the bridge is completed after the rotation procedure. This method is a safe and reliable construction method which has many advantages, such as fast construction speed without any interruption to traffic or navigation and less use of construction equipment, leading to significant economic and social benefits. This method is suitable for the construction of both singlespan and multi-span bridges, especially for those whose construction conditions are restricted by the site condition such as intersection with existing railways and highways, scenic spots, nature reserves, etc. The rotation construction method for bridges has been studied by some researchers. Saiidi et al. [3] studied the effect of the magnitude of acceleration during rotation construction on the dynamic response of a continuous concrete girder bridge. Fuchs et al. [4] elaborated the design, fabrication and installation of the EL Ferdan Railway Bridge and analyzed the mechanical performance of the rotation system. Li et al. [5] proposed a dynamic stress-free finite element method, which brings great convenience to the finite element modeling of the construction process of bridges by modifying the stress-free length of elements. Nowadays newly-built bridges are getting larger in both length and width. This causes unbalanced torque on the bridge deck in the transverse direction of these bridges, leading to torsion on the spherical hinge and the rotating girder segment when constructed with the rotation construction method [6]. In order to assure the stability and safety of the bridge during the rotation procedure, accurate prediction of the eccentricity and corresponding control measures are needed [7]. Che and Zhang [8] studied the stability of bridges during the rotation construction process. They demonstrated that the eccentricity of the cantilever bridge girder has a great impact on the overturning stability of the bridge girder during the rotation procedure. Based on the research results, they pointed out that strictly controlling the construction error is one of the most important measures for assuring the safety and reliability of the bridge. The rotation construction control is one of the key technologies in bridge rotation construction [9]. However, research on this topic is still lacking. In this study, the structural performance of a hybrid-girder cable-stayed bridge with single pylon and single cable plane during rotation construction is studied based on the finite element analysis. The deflection and the stress of the bridge girder and the deformation of the pylon at different construction stages during the rotation construction process are investigated. The results from this study may provide useful reference for the design and control of rotation construction of hybrid girder cable-stayed bridges in the future.

\section{Rotation Construction}

The basic force transfer mechanism of the rotation system is as follows: the weights of the rotating girder segment and the pier pass through the upper spherical hinge to the lower spherical hinge which is supported by the down-turntable (Figure 1). The spherical hinge is the core of the rotating system, which is composed of the upper and lower spherical hinges and the tetrafluoroethylene lamina between them. After the bridge girder is constructed outside its designated position, the support brackets of the rotating girder segment are removed and the weight of the girder is transferred to the lower spherical hinge. Then, the weight of the bridge girder is measured and the counterweight is calculated and added to balance the rotation system. Finally, the rotating body is rotated to the design position by pulling the traction cables in the upper spherical hinge with a jack system.

\section{Rotation system for the bridge}

The rotation system is composed of four main components: the

*Corresponding author: Lu Deng, Professor, Hunan Provincial Key Laboratory for Damage Diagnosis for Engineering Structures, College of Civil Engineering, Hunan University, Changsha 410082, Hunan, China, Tel: 86-731-88823320; E-mail: denglu@hnu.edu.cn

Received December 07, 2017; Accepted December 13, 2017; Published December 14, 2017

Citation: Liu B, Wang Z, Deng L, Dong S (2017) Structural Performance of a Hybrid Girder Cable-Stayed Bridge during Rotation Construction. J Steel Struct Constr 4: 137. doi: 10.4172/2472-0437.1000137

Copyright: () 2017 Liu B, et al. This is an open-access article distributed under the terms of the Creative Commons Attribution License, which permits unrestricted use, distribution, and reproduction in any medium, provided the original author and source are credited. 


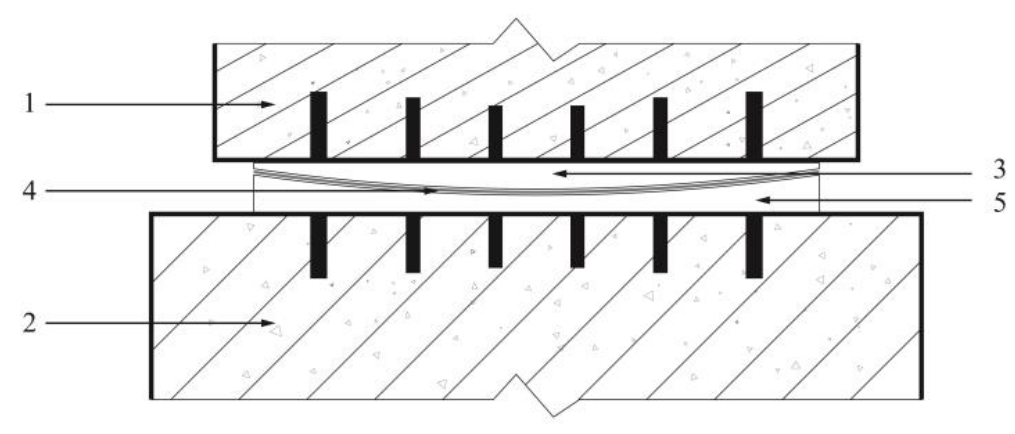

Figure 1: Constitution of the rotation system.

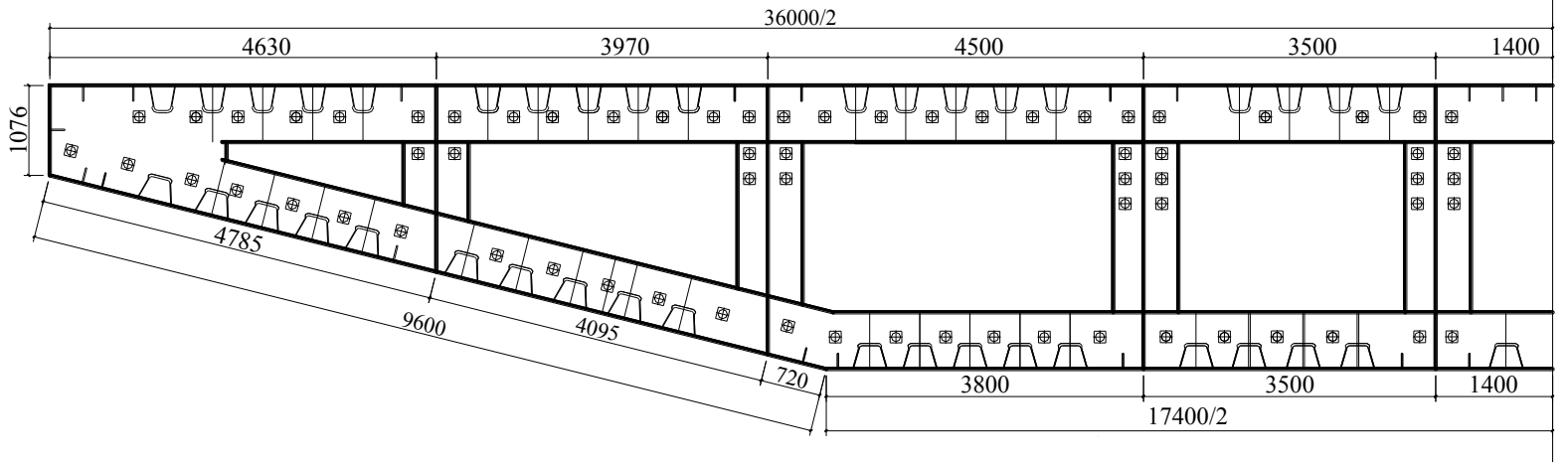

Figure 2: Cross section of the steel box girder (unit: $\mathrm{mm}$ ).

down-turntable, the spherical hinge, the up-turntable and the traction system. The down-turntable supports the total weight of the rotating body and acts as the foundation together with the up-turntable after the rotation construction is completed. The down-turntable also serves as the base for the annular slide track and the reaction seat of the Jack. The rotation bearing is the key component of the rotation system. Successful completion of the rotation construction requires accurate fabrication and installation of the rotation bearing. The arm braces are used to ensure the stability of the rotation system during the rotation procedure. They are evenly set following a circle for better distribution of the loads borne by the rotation system. The arm braces will slide along the slide track during the rotating process. The up-turntable experiences complicated stresses during the rotation procedure. The traction force is applied directly on the up-turntable.

\section{Construction process}

The process of the rotation construction is summarized as follows: Assembling the reinforcement for the down-turntable and installing the slide track $\rightarrow$ Pouring the concrete for the down-turntable $\rightarrow$ Installing the lower spherical hinge $\rightarrow$ Cleaning the lower spherical hinge and installing tetrahedron sheets $\rightarrow$ Installing the upper spherical hinge $\rightarrow$ Installing the arm braces $\rightarrow$ Assembling the reinforcement for the up-turntable $\rightarrow$ Pouring the concrete for the up-turntable $\rightarrow$ Pouring the concrete for piers and the rotating girder segment $\rightarrow$ Removing the support brackets of the up-turntable and rotating girder segment $\rightarrow$ Rotating the structure $\rightarrow$ Sealing the spherical hinge.

\section{Project Overview}

\section{Description of the bridge under consideration}

The bridge under consideration is a railway overpass on the Dongfeng Road in Siping City. It is a hybrid girder cable-stayed bridge with single pylon and single cable plane. The main span of the bridge is $169 \mathrm{~m}$ and adopts a steel box girder. The side span of the bridge is $90 \mathrm{~m}$ and uses a pre-stressed concrete box girder. The joint of the steel and the concrete girders is a steel-concrete composite (SCC) section. The bridge has a total of 24 stay cables which are arranged at a spacing of $8 \mathrm{~m}$ on the main span and at a spacing of $6 \mathrm{~m}$ on the side span. The main pylon has a height of $75 \mathrm{~m}$ and is a concrete-filled steel tubular column with an elliptical cross section. The bridge is $36 \mathrm{~m}$ in width and has six lanes, three in each direction. The cross sections of the steel and concrete girders are shown in Figures 2 and 3, respectively. The rendering picture of the bridge is shown in Figure 4.

The bridge was constructed with the rotation construction method. The main bridge structure was constructed along the direction of the railway and was then rotated to the designated location by a counter clock wise rotation angle of 87.5 degrees. Finally, post-casting was used to complete the construction of the bridge. The rotating girder segment includes the $145 \mathrm{~m}$ long steel segment of the main span and the $78 \mathrm{~m}$ long concrete segment of the side span. The mass of the rotating body is 25,500 tons.

\section{Parameters of the rotation system}

In this project, concrete of grade C50 was used for the down- 


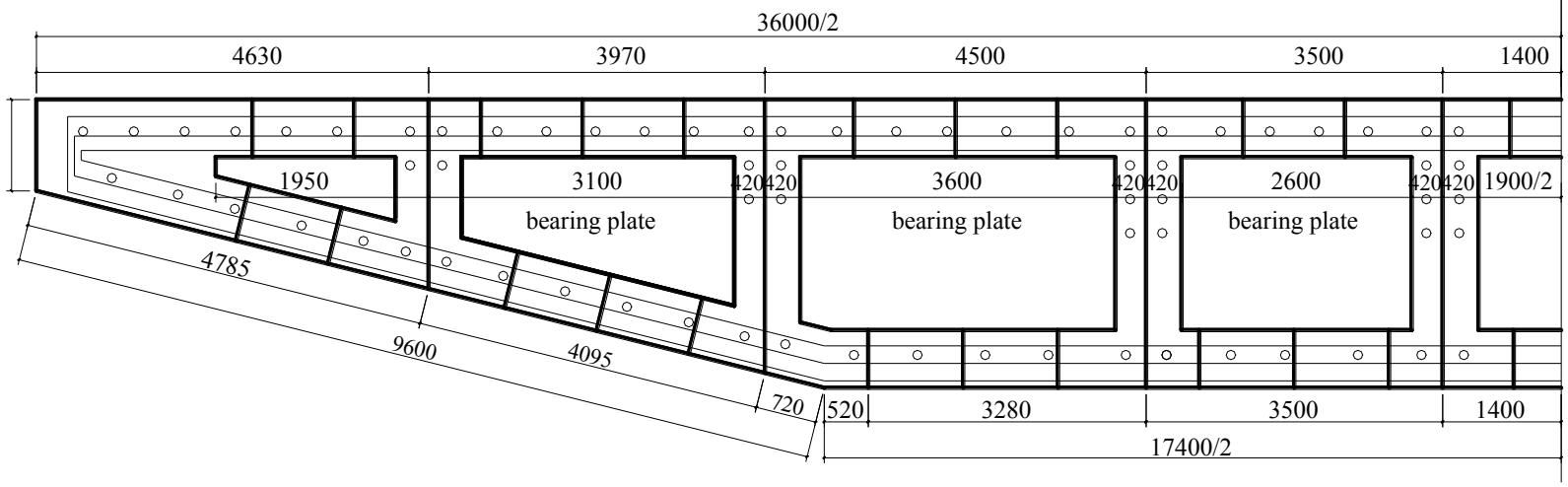

Figure 3: Cross section of the concrete box girder (unit:mm).

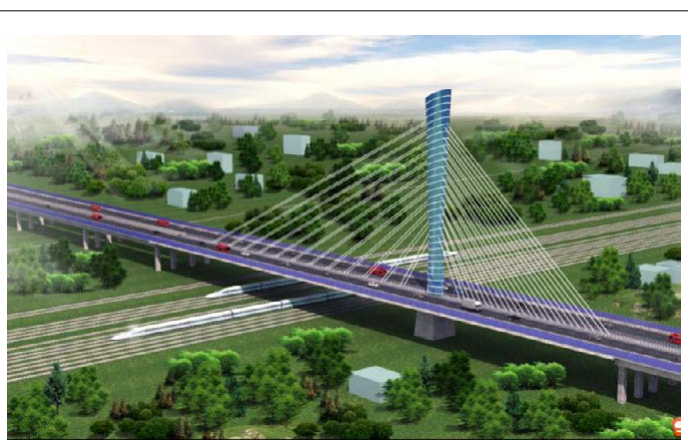

Figure 4: Rendering picture of the bridge.

turntable. A rotation bearing with bearing capacity of $350,000 \mathrm{kN}$ was adopted. The rotation bearing is $5,100 \mathrm{~mm}$ in diameter and 470 $\mathrm{mm}$ in height. The annular slide track was set at the top surface of the down-turntable, with an inner and outer diameter of $3.8 \mathrm{~m}$ and $6.0 \mathrm{~m}$, respectively. The up-turntable has a height of $3.8 \mathrm{~m}$ and is reinforced with longitudinal and transverse pre-stressing tendons.

\section{Bridge Model and Loads}

\section{Finite element bridge model}

The commercial software Midas/Civil/2015 was employed in the finite element analysis in this study. In consideration of the structural characteristics and the construction process of the bridge, the grillage method was used to build the finite element (FE) model of the bridge. The model includes 1,618 nodes and 5,172 elements. The whole bridge was modeled with beam elements except the stay cables which were modeled with truss elements. The finite element model of the bridge is shown in Figure 5.

\section{Loads}

The main loads that the bridge experiences are introduced in the following section.

Dead loads: The dead loads of the bridge include the weight of pylon, girders, diaphragms, stay-cables, etc. The characteristics of main dead loads of the bridge are summarized in Table 1.

Live loads: The City-A class live load specified in the Code for Design of the Municipal Bridge [10] was adopted in the present study. The dynamic amplification factor was taken as 1.3.

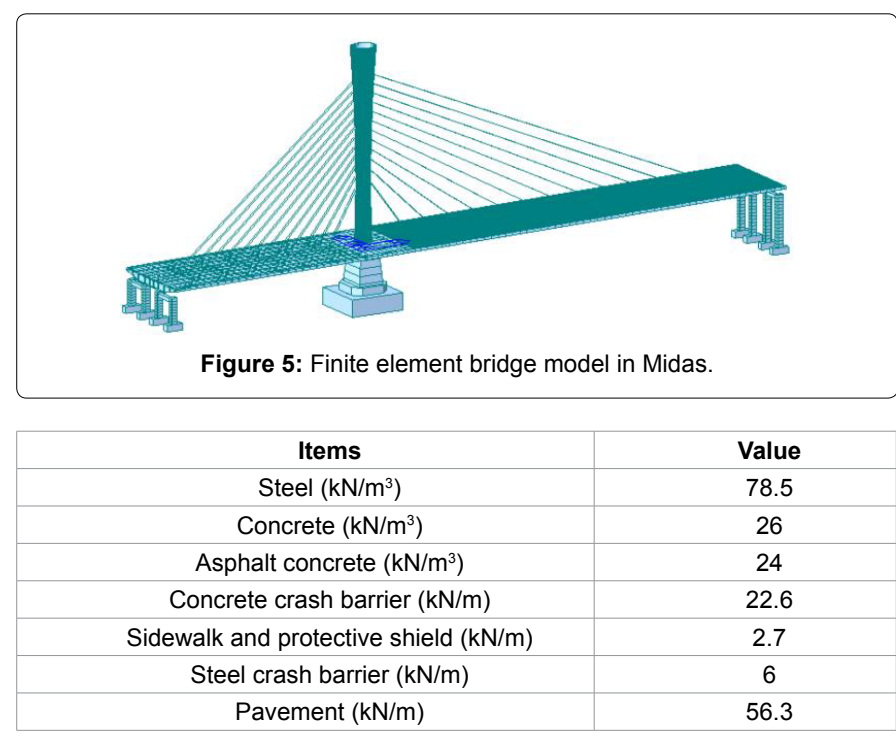

Table 1: Dead loads of the bridge.

Temperature: According to the geographic location of the bridge site, the design temperature for the closure of bridge is in the range of $10 \sim 15^{\circ} \mathrm{C}$. For concrete structures, the limits for temperature rising and dropping are $18^{\circ} \mathrm{C}$ and $28^{\circ} \mathrm{C}$, respectively. For steel structures, the limits for temperature rising and dropping are $29^{\circ} \mathrm{C}$ and $45^{\circ} \mathrm{C}$, respectively. Temperature difference between the cable and the structure is taken as $\pm 10^{\circ} \mathrm{C}$. The temperature difference caused by sunlight is determined according to the Chinese bridge design code [11]: for the concrete box girder: $\triangle \mathrm{T}=11.4^{\circ} \mathrm{C}$; at the tower side: $\triangle \mathrm{T}= \pm 5^{\circ} \mathrm{C}$; for the steel girder: $\triangle \mathrm{T}= \pm 10^{\circ} \mathrm{C}$.

Differential settlement: The settlement of the central pier is taken as $2 \mathrm{~cm}$ while the settlement of transition piers and piers under the approach bridge is taken as $1 \mathrm{~cm}$.

Wind load: Wind load is determined with reference to the Windresistant Design Specification for Highway Bridges (JTG/T D60-012004) [12].

Automobile braking force: Automobile braking force is determined with reference to the General Specification for Design of Highway Bridges and Culverts (JTG D60-2015) [13]. 
Citation: Liu B, Wang Z, Deng L, Dong S (2017) Structural Performance of a Hybrid Girder Cable-Stayed Bridge during Rotation Construction. J Steel Struct Constr 4: 137. doi: 10.4172/2472-0437.1000137

\section{Simulation of the main construction stages}

The process of bridge rotation construction can be divided into 35 stages, as is shown in Table 2 . The finite element bridge models at different stages are shown in Figure 6.

\section{Internal forces and displacement of the bridge structure at different construction stages}

As can be seen from Figure 7, the maximum deflections of the steel box girder and the concrete girder both occurred at their ends during the rotation stage. In contrast, the maximum deflections of the steel box girder and the concrete girder occurred at $68 \mathrm{~m}$ and $78 \mathrm{~m}$ away from the pylon, respectively, at the closure stage and at $116 \mathrm{~m}$ and $75 \mathrm{~m}$ away from the pylon, respectively, at the service stage. The maximum deflections of the bridge girder at different stages are listed in Table 3.

According to the Chinese Design Specification of Highway Cable Stayed Bridge [14], the maximum vertical deflection of the steel box girder in the main span shall not exceed $\mathrm{L} / 400$, which is calculated to be $647.5 \mathrm{~mm}$. It can be seen from Table 3 that the maximum deflection of the steel girder is $192 \mathrm{~mm}$ which is below the limit required by the Chinese bridge design code.

Figure 8 shows the deformation of the pylon at different construction stages. It can be seen from Figure 8 that the pylon tilted to the side span at the rotation stage and the closure stage, and tilted to the main span at the service stage. The maximum horizontal deviations at different stages are summarized in Table 4 . It can be seen from Table 4 that the maximum horizontal deviation reached $17 \mathrm{~mm}$, which occurred at the top of the pylon at the service stage.

Figure 9 shows the maximum bending moments of the bridge at the rotation and service stages. The maximum positive and negative bending moments are summarized in Table 5 .

Figures 10 and 11 show the stress at the upper and lower surfaces of the girder. The maximum stresses are presented in Table 6 .

\section{Pre-camber for the main girder}

The vertical deformation of the main girder under different design loads is obtained and is summarized in Table 7 . The required pre-

\begin{tabular}{|c|c|c|c|}
\hline Stage & Main task & Boundary condition & Loading condition \\
\hline 1 & $\begin{array}{l}\text { Construct the substructure of Piers \#9, \#11 } \\
\text { and \#12 }\end{array}$ & Fixed bottom of Piers \#9, \#11 and \#12 & Dead loads of Piers \#9, \#11 and \#12 \\
\hline 2 & $\begin{array}{c}\text { Set up the support brackets for the rotating } \\
\text { girder segment }\end{array}$ & $\begin{array}{l}\text { Rigid connection between Pier \#11 and bridge } \\
\text { girder }\end{array}$ & Dead loads of the girder \\
\hline 3 & $\begin{array}{c}\text { Stretch the pre-stressing tendons of the } \\
\text { rotating segment }\end{array}$ & - & $\begin{array}{c}\text { The pre-stressing forces in the steel tendons of the } \\
\text { rotating segment }\end{array}$ \\
\hline 4 & Construct the main pylon & $\begin{array}{l}\text { Fixed connection between the pylon and the } \\
\text { girder }\end{array}$ & Dead loads of the pylon \\
\hline 5 to 15 & $\begin{array}{c}\text { Stretch the Cables } \mathrm{C} 1 \text { to } \mathrm{C} 11 \text { of the rotating } \\
\text { segment to the required cable forces at } \\
\text { rotating stage }\end{array}$ & $\begin{array}{l}\text { Rigid connection between bridge girder and } \\
\text { Cables C1 to C11; } \\
\text { Rigid connection between the pylon and Cables } \\
\text { C1 to C11 }\end{array}$ & $\begin{array}{l}\text { Initial cable forces required in the stay cables during } \\
\text { the rotation procedure }\end{array}$ \\
\hline 16 & $\begin{array}{c}\text { Remove the support brackets of the rotating } \\
\text { girder segment }\end{array}$ & $\begin{array}{c}\text { Removal of the support of the rotating girder } \\
\text { segment }\end{array}$ & - \\
\hline 17 & $\begin{array}{c}\text { Apply the counterweight to the rotating girder } \\
\text { segment }\end{array}$ & - & The counterweight of the rotating girder segment \\
\hline 18 & $\begin{array}{l}\text { Set up the support brackets for the rotating } \\
\text { steel girder }\end{array}$ & $\begin{array}{l}\text { Elastic support at the end of the rotating steel } \\
\text { girder }\end{array}$ & - \\
\hline 19 & Lift the concrete girder & - & $\begin{array}{c}\text { The load of } 600 \mathrm{kN} \text { applied to the end of the rotating } \\
\text { concrete girder }\end{array}$ \\
\hline 20 & $\begin{array}{c}\text { Set up the support brackets for the rotating } \\
\text { concrete girder }\end{array}$ & $\begin{array}{c}\text { Elastic support at the end of the rotating concrete } \\
\text { girder }\end{array}$ & - \\
\hline 21 & Remove the rotating counterweight & - & Removal of the counterweight \\
\hline 22 & $\begin{array}{l}\text { Apply the temporary counterweight to the } \\
\text { steel girder at the closure stage }\end{array}$ & - & $\begin{array}{c}\text { Temporary counterweight at the end of the rotating } \\
\text { steel girder }\end{array}$ \\
\hline 23 & $\begin{array}{l}\text { Construct the post-casting section of the } \\
\text { concrete girder and the post-splice section } \\
\text { of the steel box girder; support the post- } \\
\text { construction section }\end{array}$ & $\begin{array}{l}\text { Elastic connection between bridge girder and Piers } \\
\qquad 9 \text { and } \# 12\end{array}$ & $\begin{array}{c}\text { Dead loads of the post-construction section, cross } \\
\text { beam, anchor block, steel anchor box and the } \\
\text { diaphragm }\end{array}$ \\
\hline 24 & $\begin{array}{c}\text { Remove the temporary counterweight for the } \\
\text { closure of the steel girder }\end{array}$ & - & $\begin{array}{c}\text { Removal of the temporary counterweight at the end of } \\
\text { the rotating steel girder }\end{array}$ \\
\hline 25 & $\begin{array}{l}\text { Stretch the pre-stressing tendons of the } \\
\text { completed bridge }\end{array}$ & - & $\begin{array}{l}\text { Pre-stressing forces in the steel tendons of the } \\
\text { completed bridge }\end{array}$ \\
\hline 26 & $\begin{array}{c}\text { Apply the permanent counterweight to girder } \\
\text { segment } \# 12\end{array}$ & - & $\begin{array}{l}\text { Permanent counterweight at the end of girder segment } \\
\qquad \# 12\end{array}$ \\
\hline 27 & Stretch Cable C12 to the desired cable force & $\begin{array}{c}\text { Rigid connection between bridge girder and Cable } \\
\text { C12; rigid connection between pylon and Cable } \\
\text { C12 }\end{array}$ & $\begin{array}{l}\text { Initial cable force in Cable } \mathrm{C} 12 \text { required at the current } \\
\text { stage }\end{array}$ \\
\hline 28 & $\begin{array}{l}\text { Remove the support brackets for the post- } \\
\text { construction girder section }\end{array}$ & - & - \\
\hline 29 & Apply the dead loads in phase II & - & Dead loads of pavement and guardrail, etc. \\
\hline 30 to 35 & Adjust cable forces to the final condition & - & Adjustment of the cable forces \\
\hline
\end{tabular}

Table 2: Bridge rotation construction stages. 

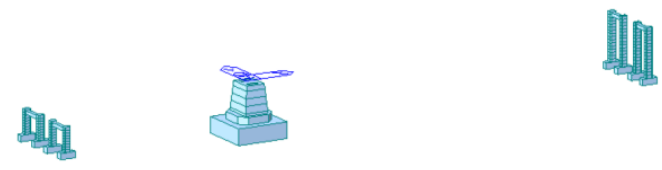

(a) Construct the substructure.

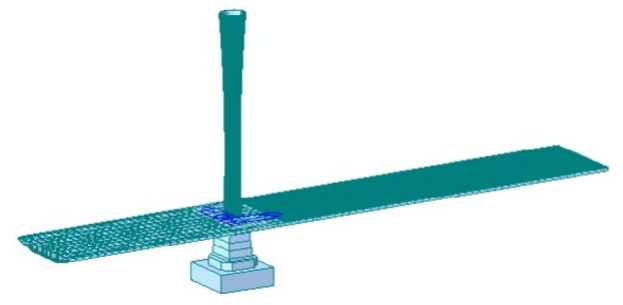

(b) Construct the plyon and rotating segment of the main girder

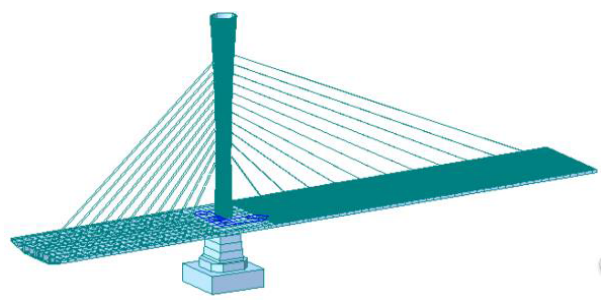

(c) Stretch the Cables $(\mathrm{C} 1$ toC11) in the rotating segment

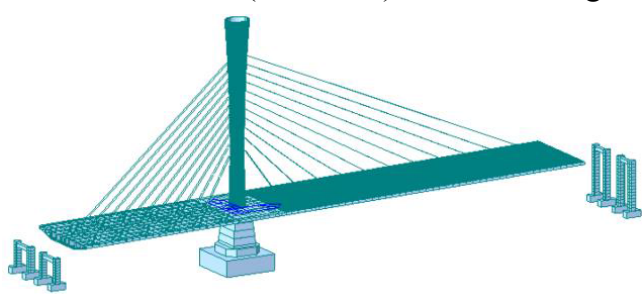

(d) Rotate the main girder to the design position

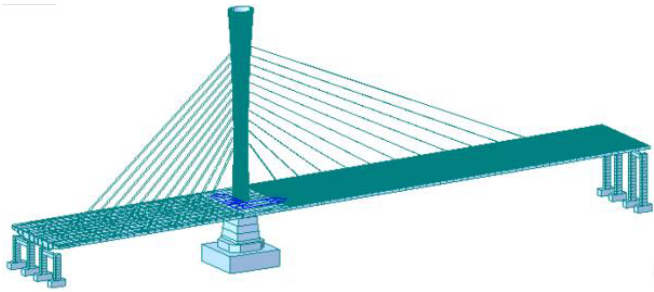

(e) Construct the post-casting concrete section and the post-splice steel section

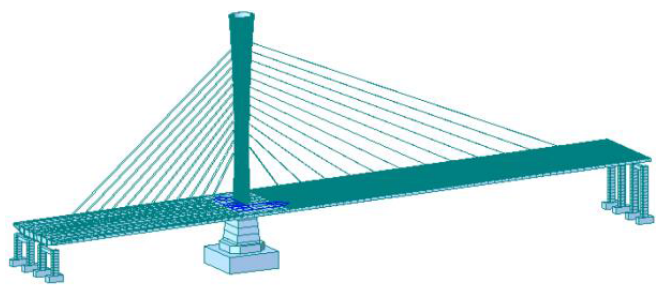

(f) Stretch Cable $\mathrm{C} 12$ of the steel girder

Figure 6: Finite element model of the bridge at typical construction stages. 
Citation: Liu B, Wang Z, Deng L, Dong S (2017) Structural Performance of a Hybrid Girder Cable-Stayed Bridge during Rotation Construction. J Steel Struct Constr 4: 137. doi: 10.4172/2472-0437.1000137

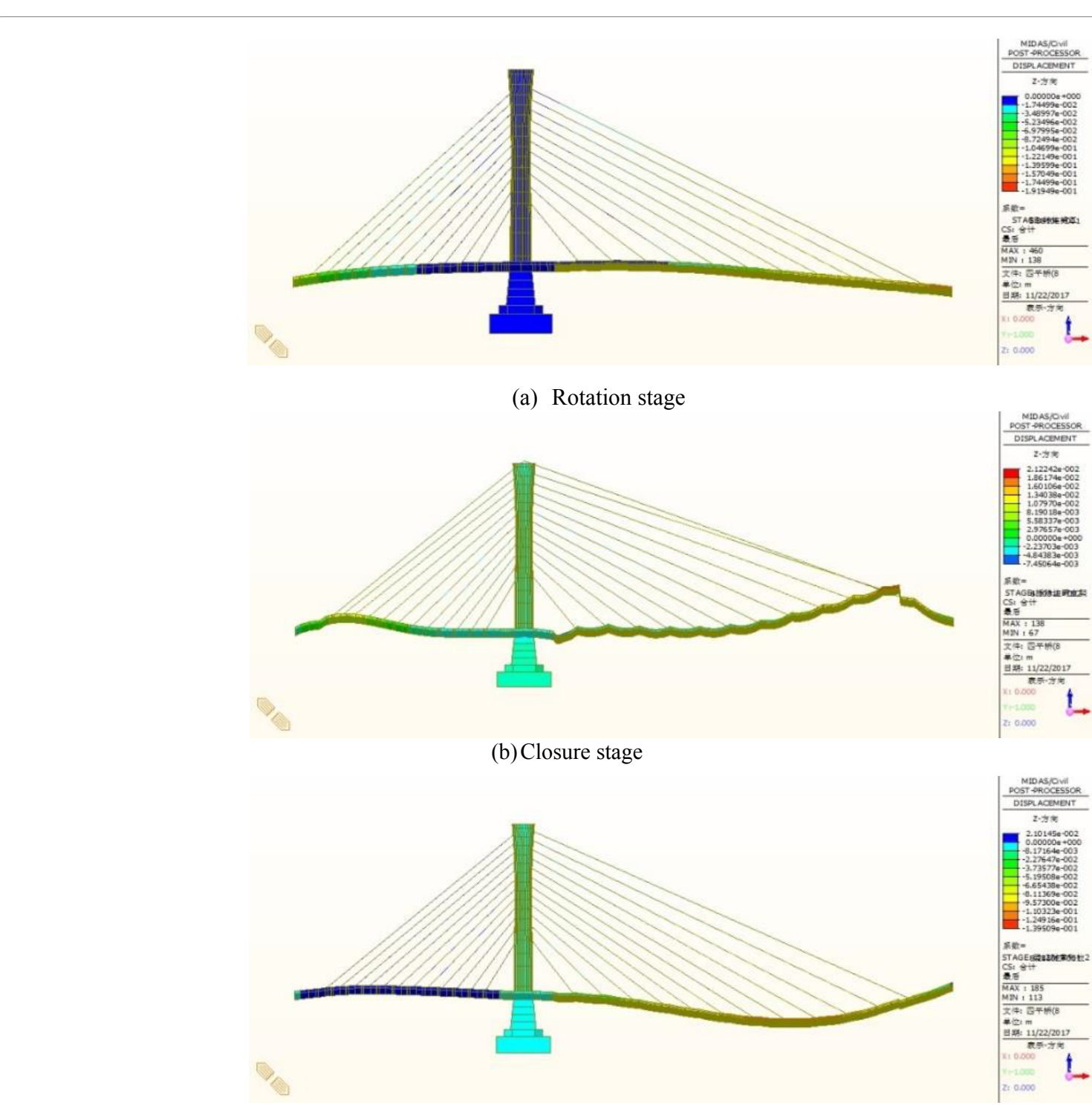

(c) Service stage

Figure 7: Deflection of the main girder.

\begin{tabular}{|c|c|c|c|}
\hline Stage & Girder segment & Maximum positive moment $(\mathrm{kN} \cdot \mathrm{m})$ & Maximum negative moment $(\mathrm{kN} \cdot \mathrm{m})$ \\
\hline \multirow[t]{2}{*}{ Rotation stage } & Concrete girder & 0 & 106,078 \\
\hline & Steel girder & 6,966 & $-25,765$ \\
\hline \multirow[t]{2}{*}{ Service stage } & Concrete girder & 99,118 & $-150,258$ \\
\hline & Steel girder & 60,885 & $-79,465$ \\
\hline
\end{tabular}

Table 3: The maximum deflections of the bridge girder.

\begin{tabular}{|c|c|}
\hline Stage & Horizontal deviation $(\mathbf{m m})$ \\
\hline Rotation stage & $-2(\leftarrow)$ \\
\hline Closure stage & $-5(\leftarrow)$ \\
\hline Service stage & $17(\rightarrow)$ \\
\hline
\end{tabular}

Table 4: Horizontal deviation at the top of the pylon.

camber is also calculated based on these results. From the finite element analysis results, it is found that the upward deflection of the concrete girder under transverse pre-stressing is very small, and the downward deflection of the steel box girder is also small due to the large stiffness

\begin{tabular}{|c|c|c|c|}
\hline \multirow{2}{*}{ Stage } & Girder segment & $\begin{array}{c}\text { Upward deflection } \\
(\mathbf{m m})\end{array}$ & $\begin{array}{c}\text { Downward } \\
\text { deflection (mm) }\end{array}$ \\
\hline \multirow{2}{*}{ Rotation Stage } & Steel girder & - & 192 \\
\cline { 2 - 4 } & Concrete girder & - & 78 \\
\hline \multirow{2}{*}{ Closure Stage } & Steel girder & 21 & - \\
\cline { 2 - 4 } & Concrete girder & 7 & - \\
\hline \multirow{2}{*}{ Service Stage } & Steel girder & - & 21 \\
\cline { 2 - 4 } & Concrete girder & - & 140 \\
\hline
\end{tabular}

Table 5: Maximum bending moment at the rotation and service stages. 
Citation: Liu B, Wang Z, Deng L, Dong S (2017) Structural Performance of a Hybrid Girder Cable-Stayed Bridge during Rotation Construction. J Steel Struct Constr 4: 137. doi: 10.4172/2472-0437.1000137

Page 7 of 9
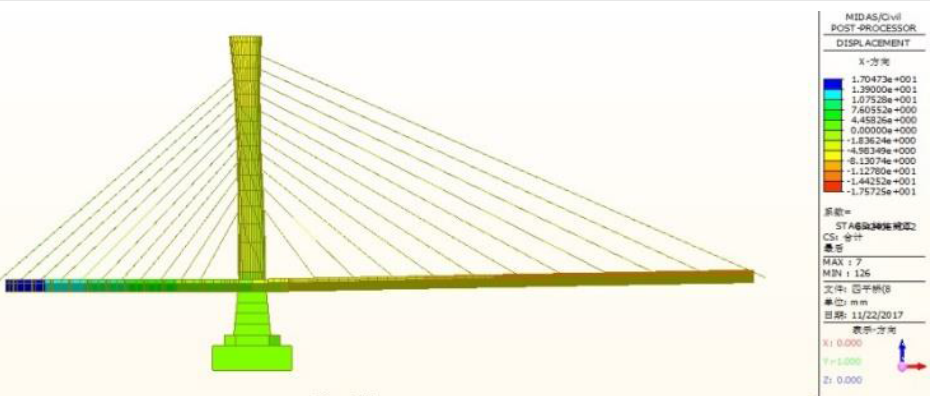

(a) Rotation stage
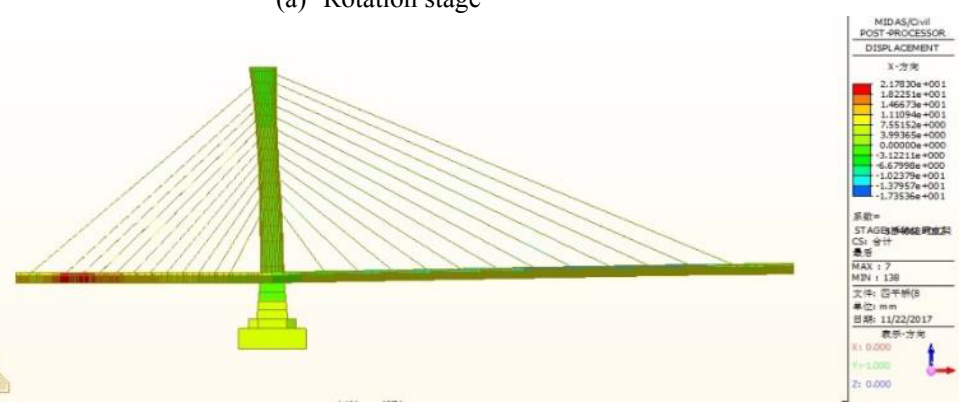

(b) Closure stage
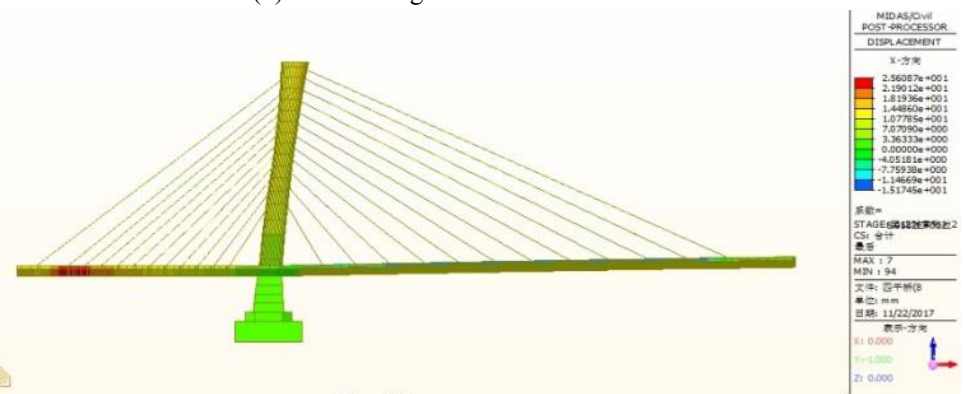

(c) Service stage

Figure 8: Horizontal deviation of the pylon at different construction stages.

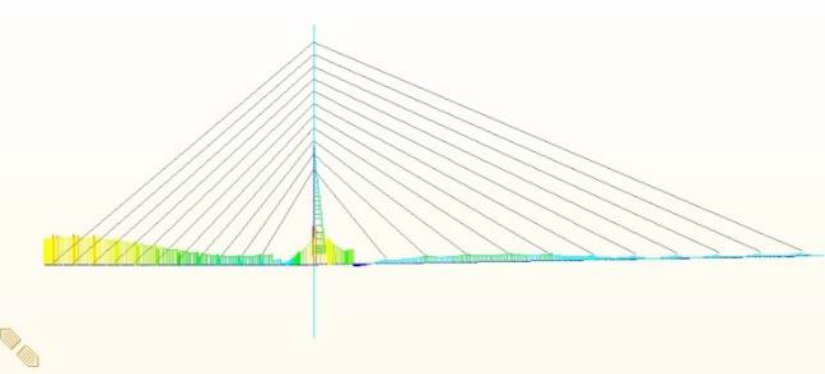

(a) Rotation stage

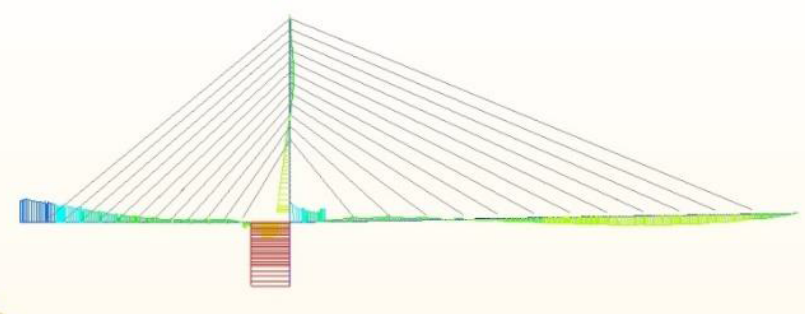

(b) Service stage

Figure 9: Maximum bending moment at the rotation and service stages.
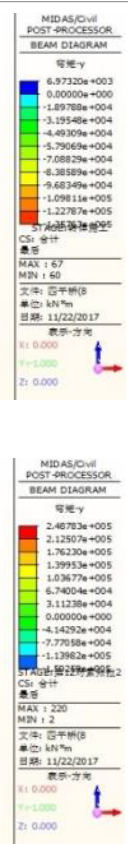
Citation: Liu B, Wang Z, Deng L, Dong S (2017) Structural Performance of a Hybrid Girder Cable-Stayed Bridge during Rotation Construction. J Steel Struct Constr 4: 137. doi: 10.4172/2472-0437.1000137

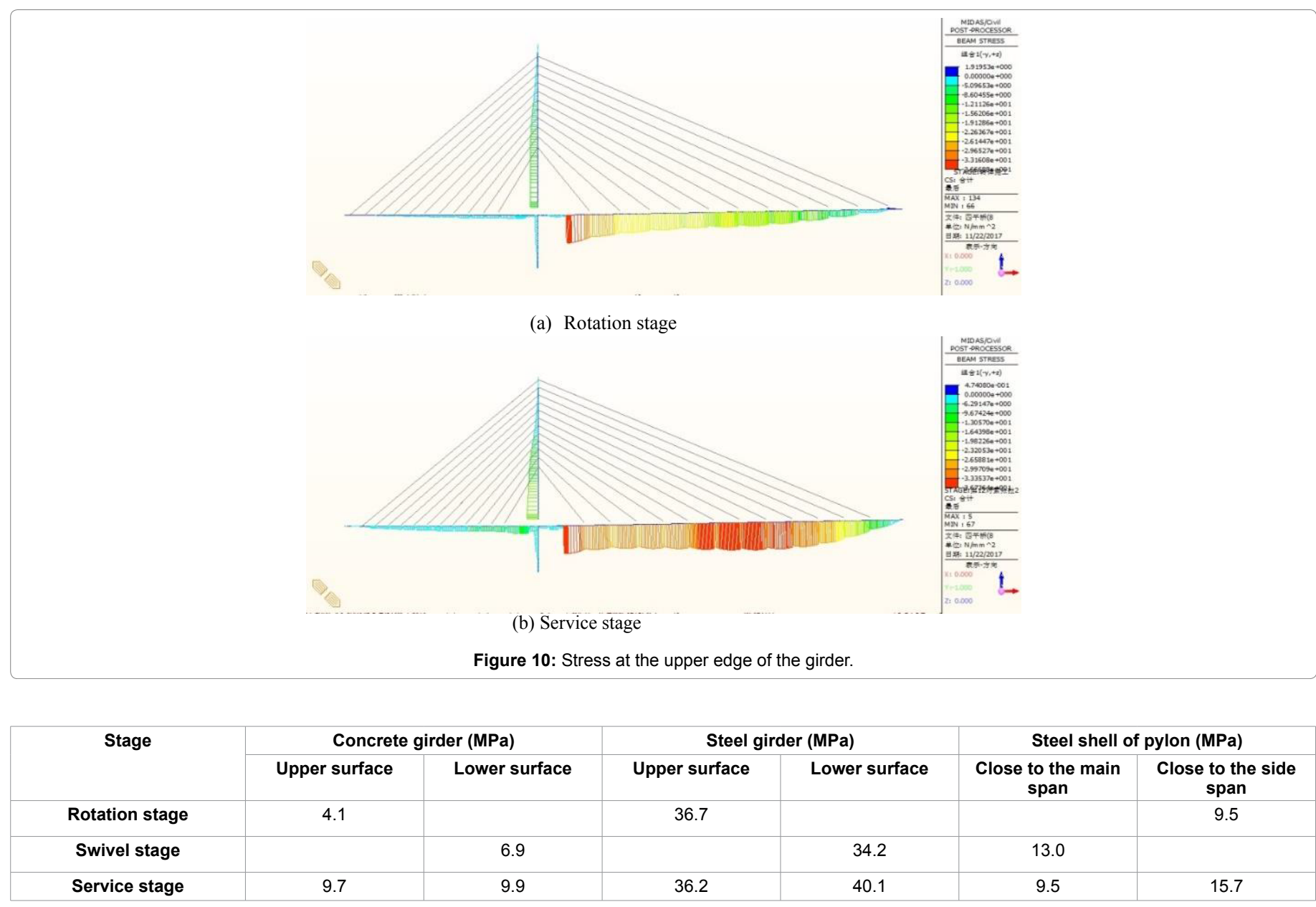

Table 6: Maximum compressive stresses at the surfaces of the girder and the pylon.

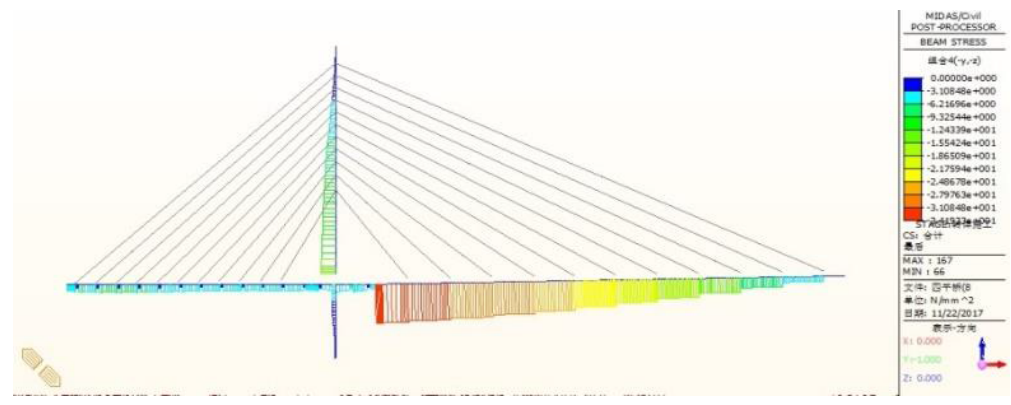

(a) Rotation stage

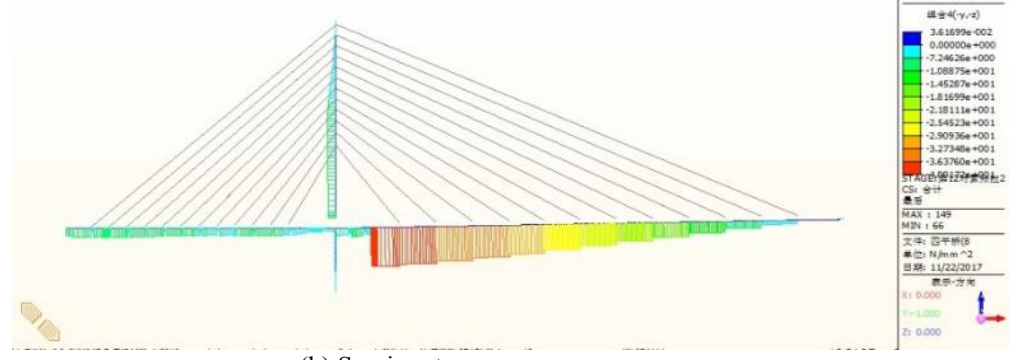

(b) Service stage

Figure 11: Stress at the lower surface of the girder. 
Citation: Liu B, Wang Z, Deng L, Dong S (2017) Structural Performance of a Hybrid Girder Cable-Stayed Bridge during Rotation Construction. J Steel Struct Constr 4: 137. doi: 10.4172/2472-0437.1000137

Page 9 of 9

\begin{tabular}{|c|c|c|c|c|}
\hline $\begin{array}{l}\text { Distance from the } \\
\text { pylon }(m)\end{array}$ & $\begin{array}{l}\text { Deflection due to dead } \\
\text { loads }(\mathrm{mm})\end{array}$ & $\begin{array}{l}\text { Frequent value of upward deflection } \\
\text { induced by crowd load ( } \mathrm{mm})\end{array}$ & $\begin{array}{l}\text { Frequent value of downward deflection } \\
\text { induced by crowd load ( } \mathrm{mm})\end{array}$ & Pre-camber (mm) \\
\hline-78.00 & 12.3 & 3.8 & -3.5 & -12.5 \\
\hline-72.10 & 17.5 & 5.6 & -5.3 & -17.9 \\
\hline-66.10 & 20.3 & 7.2 & -6.7 & -20.7 \\
\hline-60.10 & 21.0 & 8.2 & -7.7 & -21.5 \\
\hline-54.10 & 20.4 & 8.8 & -8.2 & -21.0 \\
\hline-48.10 & 18.8 & 8.9 & -8.1 & -19.6 \\
\hline-42.10 & 16.7 & 8.5 & -7.6 & -17.6 \\
\hline-36.10 & 14.2 & 7.7 & -6.7 & -15.3 \\
\hline-30.10 & 11.6 & 6.6 & -5.5 & -12.7 \\
\hline-24.10 & 8.6 & 5.3 & -4.2 & -9.8 \\
\hline-14.70 & 3.2 & 3.0 & -2.1 & -4.2 \\
\hline-12.00 & 1.8 & 2.4 & -1.5 & -2.7 \\
\hline 11.59 & -7.8 & 0.5 & -2.6 & 10.0 \\
\hline 21.04 & -14.0 & 1.2 & -16.0 & 28.9 \\
\hline 33.22 & -26.9 & 2.0 & -29.4 & 54.2 \\
\hline 42.79 & -44.5 & 2.7 & -41.2 & 83.0 \\
\hline 54.79 & -66.7 & 3.5 & -56.8 & 120.0 \\
\hline 66.78 & -89.3 & 4.3 & -72.9 & 157.9 \\
\hline 78.78 & -111.6 & 5.0 & -88.3 & 194.8 \\
\hline 90.78 & -129.1 & 5.5 & -100.7 & 224.4 \\
\hline 102.78 & -138.5 & 5.7 & -108.2 & 241.0 \\
\hline 114.78 & -137.2 & 5.5 & -108.4 & 240.1 \\
\hline 127.27 & -122.0 & 5.0 & -99.0 & 216.0 \\
\hline 139.27 & -92.8 & 4.0 & -79.7 & 168.6 \\
\hline 151.27 & -60.2 & 2.6 & -51.4 & 109.1 \\
\hline 159.77 & -33.4 & 1.3 & -26.7 & 58.8 \\
\hline 169.07 & 2.7 & 2.5 & -0.7 & -4.4 \\
\hline
\end{tabular}

Table 7: Deflection of the main girder and pre-camber.

of the steel box girder. Therefore, no transverse pre-camber is needed for the concrete girder and the steel girder.

\section{Summary and Conclusions}

In this study, the structural performance of a hybrid girder cablestayed bridge during different stages in rotation construction was analyzed using the finite element analysis. Based on the results from this study, it is found that: (1) the maximum downward deflection of the concrete girder occurred at the rotation stage; the maximum downward deflection of the steel box girder occurred at the rotation stage while the maximum upward deflection occurred at the closure stage; the maximum horizontal deviation of the pylon occurred at the service stage. All these values are within the limits allowed by the Chinese bridge design code; (2) the maximum deviation of the rotating structure was $0.060 \mathrm{~m}$ during the process of rotation construction, which is also acceptable.

The results from this study provide useful reference for achieving accurate closure of the field bridge using the rotation construction method. In addition, based on the comparison of the field measurements and the simulation results on some key parameters during the rotation construction process, better control measures and guidance could be suggested for the construction of similar bridges in the future.

\section{References}

1. http://www.iitk.ac.in/nicee/wcee/article/14_S17-02-004.PDF

2. Che X, Zhang X, Zhu H (2014) Estimation of Unbalancing Torque of Rotationally Erected T-Frame Bridge on Ball Joint Stress Different Method. Journal of Bridge Construction 44: 57-61.
3. Saiidi MS, Vosooghi A, Nelson RB (2013) Shake-Table Studies of a Four-Span Reinforced Concrete Bridge. Journal of Structural Engineering 139: 1352-1361.

4. Fuchs N, Tomlinson K, Buckby R (2003) El Ferdan Bridge, Egypt: the world's longest swing bridge. Proceedings of the Institution of Civil Engineers-Bridge Engineering, Thomas Telford Ltd 156: 21-30.

5. Li WW, Zhang Z, Huang CL (2011) Application of Dynamic Unstressed State Method in Vertical Rotation Construction of Bridges. Advanced Materials Research, Trans Tech Publications 255: 988-992.

6. Zhang J, El-Diraby TE (2006) Constructability analysis of the bridge superstructure rotation construction method in China. Journal of construction engineering and management 132: 353-362.

7. Jiang L, Gao R (2010) Deformation monitoring during removal of the supporting of T-type rigid frame bridge constructed by rotation method. Procedia Engineering 4: 355-360.

8. Che XJ, Zhang XD (2013) Stability Impact Analysis of Random Dead Load Distribution to T-Rigid Frame Bridge Swivel Construction. Applied Mechanics and Materials, Trans Tech Publications 361: 1348-1352.

9. http://en.cnki.com.cn/Article_en/CJFDTOTAL-TDJS201204003.htm

10. CJJ11 (2011) Code for design of the municipal bridge. China Architecture \& Building Press.

11. CO CHC (2004) Code for Design of Highway Reinforced Concrete and Prestressed Concrete Bridges and Culverts. China communications press.

12. CO CHC (2004) Wind-resistant Design Specification for Highway Bridges. China communications press

13. $\mathrm{CO} \mathrm{CHC}$ (2015) General specifications for design of highway bridges and culverts. China communications press.

14. JTJ 027-96. Chinese Design Specification of Highway Cable Stayed Bridge. 